\title{
Faktor-Faktor Yang Mempengaruhi Proses Penyembuhan Luka Pada Pasien Post Operasi Sectio Caesaria
}

\author{
Riandari $^{\text {a }}$, Susilaningsih ${ }^{\text {a }}$, Wiwik Agustina ${ }^{a}$ \\ ${ }^{a}$ Prodi Sarjana Keperawatan, STIKes Maharani, Malang, Indonesia \\ Email korespondensi: rheariri178@gmail.com
}

\begin{abstract}
Introduction: Sectio caesarea is the birth process by giving birth to the fetus through an incision in the abdominal wall (laparotomy) and the uterine wall. In cesaria sectio sores infection can occur. Infection is one of the inhibitors of the incision wound healing process in sectio caesaria wounds. There are various factors that affect surgical wound healing such as age, nutritional status, and mobilization. The purpose of the study was to determine internal factors including age, nutritional status, and mobilization that affect the healing process of wounds in post sectio caesaria patients at Permata Bunda Hospital Malang. Method: The study design was descriptive and the population in this study were all post sectio caesaria mothers, amounting to 75 people. The number of samples that met the inclusion criteria were 35 respondents taken by means of the Total Sampling technique. Data collection techniques using questionnaires and observation sheets (checklist). Results The results of the Spearman test of internal factors that affect the post SC wound healing process found there is a relationship of nutritional status with the value $(\rho=0.00)$ and mobilization with the value $(\rho=0.00)$ in the process of healing postoperative sores in caesarean section at Permata Bunda Hospital Malang 2019. While age has no relationship with value $(\rho=0.12)$. Conclusion It is expected that post SC mothers can find out the factors that influence the healing process of post operative caesarean wounds, so that post SC mothers can analyze so that post sectio caesaria wounds do not experience infections that can affect the wound healing process becomes slow.
\end{abstract}

Keywords: age, nutritional status, mobilization, process wound healing post operative sectio caesaria

\begin{abstract}
Abstrak
Pendahuluan: Sectio caesaria adalah proses persalinan dengan cara melahirkan janin melalui insisi pada dinding abdomen (laparotomi) serta dinding uterus. Pada luka sectio cesaria dapat terjadi infeksi. Infeksi merupakan salah satu penghambat proses penyembuhan luka insisi pada luka sectio caesaria. Terdapat berbagai faktor yang mempengaruhi penyembuhan luka operasi seperti usia, status gizi, dan mobilisasi. Tujuan Penelitian : untuk mengetahui faktor-faktor internal yang meliputi usia, status gizi, dan mobilisasi yang mempengaruhi proses penyembuhan luka pada pasien post sectio caesaria di RS Permata Bunda Kota Malang. Metode: Desain penelitian adalah deskriptif dan populasi dalam penelitian ini adalah seluruh ibu post sectio caesaria yang berjumlah 75 orang. Besar sampel yang memenuhi kriteria inklusi sejumlah 35 responden yang diambil dengan cara teknik Total Sampling. Teknik pengambilan data dengan menggunakan kuesioner dan lembar observasi (ceklist). Hasil: Hasil Penelitian : Hasil dari uji Spearman faktor-faktor internal yang mempengaruhi proses penyembuhan luka post SC didapatkan ada hubungan status gizi dengan nilai $(\rho=0.00)$ dan mobilisasi dengan nilai $(\rho=0.00)$ pada proses penyembuhan luka post operasi sectio caesaria di RS Permata Bunda Malang tahun 2019. Sedangkan usia tidak terdapat hubungan dengan nilai $(\rho=0.12)$. Kesimpulan: Diharapkan ibu post SC dapat mengetahui faktor-faktor yang mempengaruhi proses penyembuhan
\end{abstract}


PROFESIONAL HEALTH JOURNAL

Volume 2, No. 1, Desember 2020 (Hal. 22-37)

https://www.ojsstikesbanyuwangi.com/index.php/PHJ

luka post operasi sectio caesaria, sehingga ibu post SC dapat berantisispasi agar luka post sectio caesaria tidak mengalami infeksi yang dapat mempengaruhi proses penyembuhan luka menjadi lambat.

Kata kunci: umur, status gizi, mobilisasi, proses penyembuhan luka post operasi sectio caesaria

\section{PENDAHULUAN}

Persalinan merupakan fase terakhir yang terpenting dalam proses kehamilan. Masa inilah yang banyak mendebarkan seorang wanita yang melahirkan, juga pasangannya. Oleh karena itu, persalinan merupakan puncak dari segala proses dan upaya yang selama ini dilakukan agar semuanya berakhir dengan lancar, yaitu ibunya dapat melahirkan dalam keadaan sehat dan bayinya sempurna. Sectio caesarea. secara umum adalah didefinisikan sebagai proses persalinan dengan cara melahirkan janin melalui insisi pada dinding abdomen (laparotomi) serta dinding uterus (Cunningham,Maryunani, 2015).

Tujuan dari kelahiran sectio caesaria adalah memelihara kehidupan atau kesehatan ibu dan janinnya. Selain itu tindakan sectio caesaria dilaksanakan dalam keadaan dimana penundaan kelahiran akan memperburuk keadaan janin, ibu atau keduanya, sedangkan kelahiran pervaginam tidak mungkin dilakukan dengan aman (Hartati \& Maryunani, 2015). Indikasi sectio caesarea disebabkan oleh 2 faktor yaitu faktor Ibu dan Janin. Faktor ibu antara lain disproporsi kepala panggul/ CPD/FPD, disfungsi uterus, distosiajaringan lunak dan plasenta previa. Sedangkan faktor janin antara lain Janin besar, gawat janin, dan letak lintang (Jitowiyono, Kristiyanasari,2015). World Health Organization (WHO) memperkirakan bahwa angka persalinan dengan sectio caesaria sekitar 10\% sampai 15\% (Julianti, 2016). Di Indonesia terjadi peningkatan persalinan dengan sectio caesaria, pada tahun 2000 sebesar 47,22\%, ditahun 2005 sebesar 51,59\% dan tahun 2010 sebesar 53,68\% (Partini, 2016). Berdasarkan data dari RSUPN Cipto Mangunkusumo, menyebutkan bahwa dari persalinan sebanyak 404 perbulan, $30 \%$ diantaranya merupakan persalinan sectio caesaria. Hasil dari persentase tersebut, 13,7\% disebabkan oleh gawat janin dan 2,4\% karenan ukuran janin terlalu besar sehingga tidak dapat melewati panggul ibu dan sisanya sekitar $13,9 \%$ tanpa pertimbangan medis (Julianti, 2016). Menurut data riset kesehatan (Riskesdas, 2013) menunjukkan SC 9,8\%, dengan proporsi tertinggi di DKI Jakarta $(19,9 \%)$ dan terendah di Sulawesi Tenggara (3,3\%). Angka persalinan Sectio Caesaria di provinsi Lampung tahun 2013 menurut hasil Riskesdas sekitar 4,5\%, angka kejadian SC di Kota Bandar Lampung pada tahun 2012 adalah 3.401 dari 170.000 persalinan (20\%) dari seluruh persalinan.

Pada prinsipnya luka tersebut memerlukan proses penyembuhan. Penyembuhan luka adalah proses pergantian dan perbaikan fungsi jaringan yang rusak. Penyembuhan luka melibatkan integrasi proses fisiologis. Insisi bedah yang bersih merupakan contoh luka dengan sedikit jaringan yang hilang. Luka bedah 


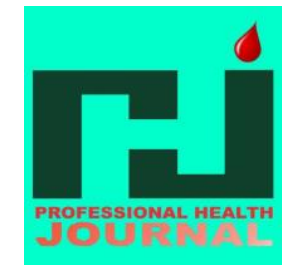

akan mengalami penyembuhan primer (primary intention). Tepi-tepi kulit merapat atau saling berdekatan sehingga mempunyai risiko infeksi yang rendah dan penyembuhan terjadi dengan cepat. Proses penyembuhan luka terdiri dari 3 fase yaitu inflamasi, proliferasi (epitelisasi) dan maturasi (remodelling), masing -masing fase memiliki ciri tersendiri. Pada luka sectio cesaria dapat terjadi infeksi. Infeksi merupakan salah satu penghambat proses penyembuhan luka insisi pada luka sectio caesaria. Terdapat berbagai faktor yang mempengaruhi penyembuhan luka operasi seperti usia, status gizi, mobilisasi, infeksi, sirkulasi dan oksigenasi,obat-obatan, dan keadaan luka (Nurani, 2015).

Penyembuhan luka secara normal memerlukan nutrisi yang tepat. Proses penyembuhan luka bergantung pada tersedianya protein, vitamin A dan C, mineral renit zink dan tembaga. Kebutuhan protein dan kalori pada pasien yang luka besar cenderung lebih tinggi dari pada kebutuhan orang sehat. Asam amino diperlukan untuk sintesis protein sruktural seperti kolagen dan untuk melakukan sintesa protein yang berperan dalam proses respon imun. Malnutrisi merupakan penyebab yang sangat penting dari kelambatan penyembuhan luka (Al Fady, 2015).

Makanan yang dikonsumsi oleh ibu nifas harus bermutu, bergizi dan cukup kalori. Konsumsi menu seimbang perlu diperhatikan untuk masyarakat, sebagai contoh menu seimbang diantaranya makanan sehat yang terdiri dari nasi, lauk, sayuran dan ditambah satu telur setiap hari (Manuaba, 2015). Ibu nifas yang
PROFESIONAL HEALTH JOURNAL

Volume 2, No. 1, Desember 2020 (Hal. 22-37)

https://www.ojsstikesbanyuwangi.com/index.php/PHJ berpantang makan, kebutuhan nutrisi akan berkurang sehingga makanan yang dikonsumsi sebaiknya mengandung protein, banyak cairan, sayur-sayuran dan buah-buahan. dan ini akan mempengaruhi dalam proses penyembuhan luka post operasi Sectio Caesaria, yaitu mengakibatkan luka menjadi tidak sembuh dengan baik atau tidak normal (Manuaba, 2015).

Sedangkan ibu yang nutrisinya sudah cukup akan tetapi masih mengikuti adat kebiasaan pantang makan seperti yang telah dikatakan oleh orangtua, sehingga bisa juga menyebabkan proses penyembuhan luka post operasi Sectio Caesria menjadi kurang baik, artinya lambat penyembuhannya. Sedangkan ibu nifas yang nutrisinya sudah cukup baik maka proses penyembuhan luka post operasi Sectio Caesarea akan lebih cepat sembuh (Mas'adah, 2016). Protein juga merupakan zat makanan yang sangat penting untuk membuntuk jaringan baru, sehingga sangat baik dikonsumsi oleh ibu nifas agar luka post operasi sectio caesarea cepat sembuh. Namun jika makanan berprotein ini dipantang maka proses penyembuhan luka post operasi sectio caesarea akan berjalan lambat, dan hal ini dapat memicu terjaadinya infeksi pada luka post operasi sectio caesarea (Manuaba, 2015).

Mobilisasi juga dapat mempercepat proses penyembuhan luka, dengan melakukan mobilisasi ibu merasa lebih sehat, kuat dan dapat mengurangi rasa sakit dengan demikian ibu memperoleh kekuatan, mempercepat kesembuhan, fungsi usus dan kandung kemih lebih baik, 
PROFESIONAL HEALTH JOURNAL

Volume 2, No. 1, Desember 2020 (Hal. 22-37)

https://www.ojsstikesbanyuwangi.com/index.php/PHJ

merangsang peristaltik usus kembali normal dan mobilisasi juga membantu mempercepat organ-organ tubuh bekerja seperti semula (Hartati \& M

aryunani, 2015).

Menurut penelitian sebelumnya, yang dilakukan oleh (Hasmanidar , 2015) tentang faktor- faktor yang mempengaruhi lamanya penyembuhan luka post operasi sectio caesaria di RSUD Zainoel Abidin menunjukan ada hubungan. Hasil analisa statistik menggunakan uji chi-square menunjukkan hubungan tersebut bermakna dengan $p$ value $=0,025$ yang menunjukkan bahwa terdapat pengaruh usia terhadap lamanya penyembuhan luka pasca sectio caesaria sebanyak (69,2\%). Terdapat pengaruh gizi terhadap lamanya penyembuhan luka pasca sectio caesaria sebanyak (76,5\%). Hasil analisa statistik menggunakan uji chi-square menunjukkan hubungan tersebut bermakna dengan $p$ value $=0,001$ yang menunjukkan bahwa terdapat pengaruh mobilisasi terhadap lamanya penyembuhan luka pasca sectio caesaria sebanyak $(69,1 \%)$.

Sedangkan menurut penelitian yang di lakukan oleh Nirwana Perangin (2014) di RSUD Ratu Zalecha Martapura hasil penelitian menunjukan bahwa tidak ada hubungan. Dari 153 ibu dengan umur aman, didapatkan 139 ibu (90,8\%) yang lukanya sembuh dan dari 44 ibu dengan umur tidak aman didapatkan 40 ibu (90,9\%) yang lukanya tidak sembuh. Hasil analisa statistik dengan menggunakan uji Fisher's Exact didapatkan nilai $\rho$ 0,628. Dengan nilai $\rho>\alpha(0,05)$, maka dapat disimpulkan bahwa Ha diterima dan Ho ditolak, artinya tidak ada hubungan umur dengan penyembuhan luka pasca sectio cesaria di RSUD RatuZalecha Martapura tahun 2013. Dari hasil analisa statistik dengan menggunakan uji Chi Square didapatkan nilai $\rho=0,936>\alpha=0,05$, maka hipotesis penelitian ditolak, artinya tidak ada hubungan berat badan dengan penyembuhan luka pasca sectio caesaria di RSUD Ratu Zalecha Martapura tahun 2012. Menunjukkan bahwa hasil analisa statistik dengan menggunakan uji Fisher's Exact didapatkan nilai $\rho=0,621>\alpha=0,05$, maka hipotesis penelitian ditolak, artinya tidak ada hubungan personal hygiene dengan penyembuhan luka pasca sectio caesaria di RSUD Ratu Zalecha Martapura tahun 2012.

Berdasarkan dari studi pendahuluan yang dilakukan oleh peneliti pada tanggal 13-14 Oktober 2018 di RS Permata Bunda Malang dengan melakukan observasi dan wawancara kepada 10 orang ibu post sectio caesaria di Ruang Klinik Kandungan RS Permata Bunda Malang ditemukan bahwa terdapat $60 \%$ ibu post sectio caesaria yang mengalami penyembuhan luka operasi yang cukup lama (24 hari pasca operasi) salah satu penyebabnya usia ibu diatas 35 tahun dan kurangnya nutrisi yang di konsumsi oleh ibu, karena masih beranggapan bahwa makanan protein itu memicu infeksi serta beranggapan luka operasi akan lama untuk kering, di samping itu ibu juga membatasi gerak pasca operasi karena takut jahitannya putus dan terbuka sedangkan terdapat $40 \%$ ibu post sectio caesaria yang penyembuhannya cepat karena usia ibu kurang dari 35 tahun, 
PROFESIONAL HEALTH JOURNAL

Volume 2, No. 1, Desember 2020 (Hal. 22-37)

https://www.ojsstikesbanyuwangi.com/index.php/PHJ

nutrisinya cukup tidak pantangan terhadap makanan apapun serta tidak membatasi aktivitas. Berdasarkan uraian tersebut peneliti tertarik untuk melakukan penelitian tentang "Faktor-faktor yang mempengaruhi proses penyembuhan luka pada pasien post operasi sectio caesaria di RS Permata Bunda Kota Malang".

\section{METODE PENELITIAN}

Penelitian ini merupakan penelitian kuantitatif. Metode yang digunakan adalah metode diskriptif dengan menggunakan pendekatan crossectional yang mengetahui hubungan antara variabel dengan melakukan analisis terhadap faktor-faktor yang mempengaruhi proses penyembuhan luka post operasi sectio caesaria, yaitu meliputi ( umur, status gizi dan mobilisasi) dimana variabel bebas dan variabel terikat dilakukan pengukuran sekaligus dalam waktu bersamaan.

Populasi dalam penelitian ini adalah seluruh ibu post sectio caesaria yang bersalin dan datang kontrol di klinik kandungan di Rumah Sakit Permata Bunda Kota Malang yang berjumlah rata-rata perbulannya 75 orang.

Sampel yang digunakan dalam penelitian adalah seluruh ibu post sectio caesarea yang bersalin dan kontrol di klinik kandungan di Rumah Sakit Permata Bunda Malang. Sebanyak 35 orang yang sesuai dengan kriteria inklusi dan eksklusi yang di tentukan. 1. Kriteria Inklusinya adalah Semua ibu post operasi sectio caesaria baik primipara maupun multipara; Semua ibu post operasi sectio caesaria yang bersalin dan datang kontrol ke klinik kandungan RS Permata Bunda Kota Malang; dan yang bersedia menjadi responden. Sedangkan Kriteria Eksklusi adalah Ibu post operasi sectio caesaria yang datang kontrol luka di RS Permata Bunda kurang dari hari ke 24; dan Ibu yang melahirkan sectio caesaria di RS lain, kontrol luka di RS Permata Bunda.

\section{HASIL PENELITIAN}

Tabel 1. Karakteristik Responden Berdasarkan Data Umum

\begin{tabular}{|c|c|c|c|}
\hline No & $\begin{array}{c}\text { Karakteristik } \\
\text { Responden }\end{array}$ & Frekuensi & $\begin{array}{c}\text { Persentase } \\
(\%)\end{array}$ \\
\hline \multirow[t]{6}{*}{1.} & PendidikanTerakhir & & \\
\hline & SD & 6 & $28.6 \%$ \\
\hline & SMP & 8 & $22.9 \%$ \\
\hline & SMA & 17 & $48.6 \%$ \\
\hline & PT & 4 & $11.4 \%$ \\
\hline & Total & 35 & $100 \%$ \\
\hline \multirow[t]{4}{*}{3.} & Paritas & & \\
\hline & Primipara & 15 & $42,9 \%$ \\
\hline & Multipara & 20 & $57,1 \%$ \\
\hline & Total & 35 & $100 \%$ \\
\hline \multirow[t]{5}{*}{2.} & Pekerjaan & & \\
\hline & IRT & 10 & $28,6 \%$ \\
\hline & Petani & 10 & $28,6 \%$ \\
\hline & Swasta & 15 & $42,9 \%$ \\
\hline & Total & 35 & $100 \%$ \\
\hline
\end{tabular}

Sumber: Data Primer (2019)

Tabel 1 menunjukkan bahwa karakteristik responden berdasarkan pendidikan terakhir responden hampir setengahnya berpendidikan terakhir yaitu SMA sebanyak 17 orang ( $48.6 \%$ ), dan sebagian kecil berpendidikan terakhir Perguruan Tinggi sebanyak 4 orang $(11.4 \%)$. Berdasarkan pekerjaan responden hampir setengahnya bekerja swasta sebanyak 15 orang $(42.9 \%)$. Dan berdasarkan paritas responden sebagian besar multipara sebanyak 20 orang $(57,1 \%)$. 
Table 2. Distribusi Frekuensi berdasarkan faktor-faktor Internal pada penyembuhan luka post operasi $\mathrm{SC}$

\begin{tabular}{|c|c|c|c|}
\hline No & Kategori & Frekuensi & $\begin{array}{c}\text { Persentase } \\
(\%)\end{array}$ \\
\hline \multirow[t]{3}{*}{1.} & $\begin{array}{l}\text { Usia } \\
\text { 20-35 Tahun } \\
\text { Penyembuhan } \\
\text { Luka Cepat }\end{array}$ & 32 & $91.4 \%$ \\
\hline & $\begin{array}{l}\text { >35 Tahun } \\
\text { Penyembuhan } \\
\text { Luka Lambat }\end{array}$ & 3 & $8.6 \%$ \\
\hline & Total & 35 & $100 \%$ \\
\hline \multirow[t]{4}{*}{2.} & Status Gizi & & \\
\hline & $\begin{array}{l}\text { Baik } \\
\text { Cukun }\end{array}$ & $\begin{array}{l}10 \\
19\end{array}$ & $\begin{array}{l}28.6 \% \\
54.3 \%\end{array}$ \\
\hline & Kurang & 4 & $17.1 \%$ \\
\hline & Total & 35 & $100 \%$ \\
\hline \multirow[t]{5}{*}{3.} & Mobilisasi & & \\
\hline & Baik & 10 & $28.6 \%$ \\
\hline & Cukup & 19 & $54.3 \%$ \\
\hline & Kurang & 6 & $17.1 \%$ \\
\hline & Total & 35 & $100 \%$ \\
\hline
\end{tabular}

Sumber : Data Primer (2019)

Berdasarkan tabel 2 menunjukkan bahwa faktor usia hampir seluruhnya responden mengalami penyembuhan luka cepat yaitu sejumlah 32 responden $(91.4 \%)$. Berdasarkan distribusi frekuensi faktor internal pemenuhan nutrisi ibu post operasi sectio caesaria di RS Permata Bunda Malang di peroleh hasil bahwa sebagian besar responden cukup terpenuhi nutrisinya yaitu 19 responden $(54,3 \%)$. Distribusi untuk pelaksanaan mobilisasi ibu post operasi sectio caesaria di RS Permata Bunda Malang di peroleh hasil bahwa sebagian besar responden cukup dalam melakukan mobilisasi yaitu sebanyak 21 responden $(60,0 \%)$.
Table 3. Distribusi frekuensi proses penyembuhan luka post operasi sectio caesaria

\begin{tabular}{lcc}
\hline $\begin{array}{l}\text { Penyembuhan } \\
\text { Luka Post SC }\end{array}$ & Frekuensi & $\begin{array}{c}\text { Persentas } \\
\text { e (\%) }\end{array}$ \\
\hline Tidak Sembuh & 8 & $22.9 \%$ \\
Sembuh & 27 & $77.1 \%$ \\
\hline Total & 35 & $100 \%$ \\
\hline Sul
\end{tabular}

Sumber : Data Primer (2019)

Berdasarkan tabel 3 distribusi frekuensi responden dalam proses penyembuhan luka post operasi sectio caesaria di RS Permata Bunda Malang di peroleh hasil bahwa hampir seluruh responden mengalami proses penyembuhan luka sembuh yaitu 27 orang $(77.1 \%)$

Table 4. Hasil Analisis Usia dengan Penyembuhan Luka Uji Statistik Lamda

\begin{tabular}{ccc}
\hline Uji Lamda & \multicolumn{2}{c}{ Proses Penyembuhan Luka } \\
\cline { 2 - 3 } Faktor internal & $\mathrm{N}$ & 35 pasien \\
usia & $\mathrm{p}$ & 0,05 \\
& $\mathrm{r}$ & 0,121 \\
& $+0,500$ \\
\hline
\end{tabular}

Sumber : Data Primer (2019)

Berdasarkan tabel 4 hasil hipotesis dengan uji Lamda didapatkan $(\rho=0.121$; $\alpha=0,05 ; r=0,500)$. Hasil ini menunjukan bahwa tidak ada hubungan faktor internal usia ibu dengan proses penyembuhan luka post operasi sectio caesaria di RS Permata Bunda Kota Malang. Peneliti meneliti dari 35 respondene yang terbagi dalam proses penyembuhan luka post operasi sectio caesaria tidak sembuh sebanyak 3 responden dengan usia >35 tahun 
sebanyak $1 \quad(2.9 \%) \quad$ mengalami penyembuhan lukanya lambat. Dan berdasarkan yang usia 20-35 tahun sebanyak $22(68.8 \%)$ penyembuhan luka post operasi sectio caesaria menunjukkan sembuh.

Tabel 5. Tabulasi silang Hubungan Usia dengan Proses Penyembuhan Luka post Operasi Sectio Caesaria

\begin{tabular}{|c|c|c|c|c|c|c|}
\hline \multirow[t]{2}{*}{ Usia } & \multicolumn{4}{|c|}{ Penyembuhan Luka } & \multirow[b]{2}{*}{$\mathbf{F}$} & \multirow[b]{2}{*}{$\%$} \\
\hline & & mbuh & & $\begin{array}{l}\text { idak } \\
\text { mbuh }\end{array}$ & & \\
\hline $\begin{array}{l}\text { 20-35 } \\
\text { Tahun } \\
\text { Penye } \\
\text { mbuha } \\
\text { n Luka } \\
\text { Cepat }\end{array}$ & 25 & $71.4 \%$ & 7 & $20.0 \%$ & 32 & $\begin{array}{l}91.4 \\
\%\end{array}$ \\
\hline $\begin{array}{l}>35 \\
\text { Tahun } \\
\text { Penye } \\
\text { mbuha } \\
\text { n Luka } \\
\text { Lambat }\end{array}$ & 2 & $5.7 \%$ & 1 & $2.9 \%$ & 3 & $8.6 \%$ \\
\hline Total & & & & & 35 & $100 \%$ \\
\hline
\end{tabular}

Sumber : Data Primer (2019)

Berdasarkan tabel 5 hasil tabulasi silang dari 35 responden didapatkan bahwa sebagian besar responden yang penyembuhan luka cepat sembuh pada usia 20-35 tahun yaitu sebanyak 25 responden (71.4\%) dari total keselurahan jumlah responden yang mengalami luka tidak sembuh yaitu 10 responden. Sedangkan responden yang penyembuhan luka lambat pada usia $>35$ tahun yang sembuh sebagian kecil yaitu 2 responden $(5.7 \%)$ dari total jumlah keseluruhan responden yang tidak sembuh lukanya yaitu 1 responden $(2,9 \%)$.
Tabel 6. Hasil Analisis Status Gizi (Nutrisi) dengan Penyembuhan Luka Uji Statistik Spearman

\begin{tabular}{ccc}
\hline Uji Spearman & \multicolumn{2}{c}{ Proses Penyembuhan Luka } \\
\cline { 2 - 3 } Faktor internal & $\mathrm{N}$ & 35 pasien \\
status gizi & $\mathrm{a}$ & 0,05 \\
(nutrisi) & $\mathrm{p}$ & 0,000 \\
& $\mathrm{r}$ & $+0,680$ \\
\hline
\end{tabular}

Sumber : Data Primer (2019)

Berdasarkan tabel 6 menunjukan hasil hipotesis dengan uji spearman didapatkan $(\rho=0.000 ; \alpha=0,05 ; r=0,680)$. Hasil ini menunjukan bahwa ada hubungan faktor internal status gizi (nutrisi) dengan proses penyembuhan luka post sectio caesaria di RS Permata Bunda Kota Malang. Peneliti meneliti dari 35 responden bahwa responden yang melakukan pemenuhan nutrisi dengan baik dan sembuh sebanyak 10 orang $(28.6 \%)$ dan penyembuhan luka yang tidak sembuh dan nutrisinya kurang sebanyak 6 orang $(17.1 \%)$, responden yang nutrisinya cukup dan sembuh sebanyak 17 orang $(48.6 \%)$. Hasil penelitian ini tanda koefisien adalah positif, dengan nilai koefisien (positif) semakin status gizi (nutrisi) nya terpenuhi maka proses penyembuhan luka semakin cepat sembuh. Dengan koefisien korelasi juga dapat di tentukan kekuatan korelasi (r) yang menginterprestasikan seberapa kuat hubungan yang ditimbulkan antara 2 variabel penelitian. Hasil penelitian ini diketahui pada rentang kuat yakni 0,680 (rentang 0,60-0,799). Dengan demikian status gizi (nutrisi) menjadi faktor utama dalam proses penyembuhan luka post operasi sectio caesaria. 
PROFESIONAL HEALTH JOURNAL

Volume 2, No. 1, Desember 2020 (Hal. 22-37)

https://www.ojsstikesbanyuwangi.com/index.php/PHJ

Tabel 7. Tabulasi silang Hubungan Status Gizi (Nutrisi) dengan Proses Penyembuhan Luka post Operasi Sectio Caesaria

\begin{tabular}{llcccc}
\hline Nutrisi & Kurang & Cukup & Baik & F & \% \\
\hline Penyemb & 0 & 17 & 10 & 27 & $77.2 \%$ \\
uhan & $0 \%$ & $48.6 \%$ & $28.6 \%$ & & \\
Luka & & & & & \\
$\begin{array}{l}\text { Sembuh } \\
\text { Luka }\end{array}$ & 6 & 2 & 0 & 8 & $22.8 \%$ \\
Tidak & $17.1 \%$ & $5.7 \%$ & $0 \%$ & & \\
Sembuh & & & & & \\
\hline Total & 6 & 19 & 10 & 35 & $100 \%$ \\
& $17.1 \%$ & $54.3 \%$ & $28.6 \%$ & &
\end{tabular}

Sumber : Data Primer (2019)

Berdasarkan tabel 7, hasil tabulasi silang dapat diketahui bahwa dari 35 responden hampir setengahnya pemenuhan nutrisinya cukup dan lukanya sembuh yaitu 17 responden $(48.6 \%)$ dari total keseluruhan jumlah responden yang mengalami pemenuhan gizi kurang dan luka tidak sembuh yaitu 6 responden $(17.1 \%)$.

Tabel 8. Hasil Analisis Mobilisasi dengan Penyembuhan Luka Uji Statistik Spearman

\begin{tabular}{ccc}
\hline \multirow{2}{*}{ Uji Spearman } & \multicolumn{2}{c}{$\begin{array}{c}\text { Proses Penyembuhan } \\
\text { Luka }\end{array}$} \\
\cline { 2 - 3 } Faktor internal & $\mathrm{N}$ & 35 pasien \\
mobilisasi & $\mathrm{p}$ & 0,05 \\
& $\mathrm{r}$ & 0,000 \\
& & $+0,572$ \\
\hline
\end{tabular}

Sumber : Data Primer (2019)

Berdasarkan tabel 8 hasil hipotesis dengan uji spearman didapatkan $(\rho=$ $0.000 ; \alpha=0,05 ; r=0,572)$. Hasil ini menunjukan bahwa ada hubungan faktor internal status mobilisasi dengan proses penyembuhan luka post sectio caesaria di RS Permata Bunda Kota Malang. Peneliti meneliti dari 35 responden yang melakukan mobilisasi dengan baik dan sembuh sebanyak 10 orang $(28.6 \%)$ dan penyembuhan luka yang tidak sembuh 10 orang $(28.6 \%)$, responden yang cukup melakukan mobilisasi dan sembuh sebanyak 17 orang (48.6\%) dan yang mengalami penyembuhan luka tidak sembuh serta kurang mobilisasi sebanyak 4 orang (11.4\%). Hasil penelitian ini ditandai koefisien adalah positif, dengan nilai koefisien (positif) semakin melakukan mobilisasi maka proses penyembuhan luka semakin cepat sembuh. Dengan koefisien korelasi (r) yang menginterprestasikan sedang hubungan yang di timbulkan antara 2 variabel penelitian. Hasil penelitian ini di ketahui pada rentang sedang yakni 0,572 (rentang 0,40-0,599). Dengan demikian mobilisasi merupakan salah satu faktor yang mempengaruhi proses penyembuhan luka pada post sectio caesaria.

Tabel 9. Tabulasi silang Hubungan Mobilisasi dengan Proses Penyembuhan Luka post Operasi Sectio Caesaria

\begin{tabular}{|c|c|c|c|c|c|}
\hline Mobilisasi & Kurang & Cukup & Baik & $\mathbf{F}$ & $\%$ \\
\hline Penyembuhan & $00 \%$ & 17 & 10 & 27 & $77.2 \%$ \\
\hline Luka Sembuh & & $48.6 \%$ & $28.6 \%$ & & \\
\hline Luka Tidak & 4 & 4 & $0 \quad 0 \%$ & 8 & $22.8 \%$ \\
\hline Sembuh & $11.4 \%$ & $11.4 \%$ & & & \\
\hline Total & $411.4 \%$ & $\begin{array}{c}21 \\
60.0 \%\end{array}$ & $\begin{array}{l}10 \\
28.6 \%\end{array}$ & 35 & $100 \%$ \\
\hline
\end{tabular}

\section{Sumber : Data Primer (2019)}

Berdasarkan tabel 9 hasil tabulasi silang dapat di ketahui bahwa dari 35 responden hampir setengahnya cukup melakukan mobilisasi dan penyembuhan luka sembuh yaitu sejumlah 17 responden (48.6\%) dari total keseluruhan jumlah responden dan penyembuhan luka tidak 
PROFESIONAL HEALTH JOURNAL

Volume 2, No. 1, Desember 2020 (Hal. 22-37)

sembuh serta mobilisasi yang kurang sebanyak 4 orang $(11.4 \%)$.

\section{PEMBAHASAN}

\section{Identifikasi Hubungan Faktor Internal Usia dengan Proses Penyembuhan Luka post Sectio Caesaria}

Berdasarkan hasil hipotesis dengan uji Lamda didapatkan ( $\rho=0.12 ; \alpha=0,05 ; \mathrm{r}$ $=0,50)$. Hasil ini menunjukan bahwa tidak ada hubungan faktor internal usia ibu dengan proses penyembuhan luka post operasi sectio caesaria di RS Permata Bunda Kota Malang. Peneliti meneliti dari 35 responden yang terbagi dalam proses penyembuhan luka post operasi sectio caesaria tidak sembuh sebanyak 3 responden dengan usia > 35 tahun sebanyak $1 \quad(2.9 \%) \quad$ mengalami penyembuhan lukanya lambat. Dan berdasarkan yang usia 20-35 tahun sebanyak $22(68.8 \%)$ penyembuhan luka post operasi sectio caesaria menunjukkan sembuh

Usia dapat menganggu semua tahap penyembuhan luka seperti: perubahan vaskuler yang menganggu sirkulasi ke daerah luka, penurunan fungsi hati menganggu sintesis faktor pembekuan, respons inflamasi lambat, pembentukan antibodi dan limfosit menurun, jaringan kolagen kurang lunak, jaringan parut kurangelastis.Seiring dengan bertambahnya usia, perubahan yang terjadi di kulit yaitu frekuensi penggunaan sel epidermis, respon inflamasi terhadap cedera, persepsi sensori, proteksi mekanis, dan fungsi barier kulit. Kecepatan

perbaikan sel berlangsung sejalan dengan pertumbuhan atau kematangan usia (Nuraini, 2015).

Menurut Bartini (2013), usia reproduksi sehat adalah usia yang aman bagi seorang wanita untuk hamil dan melahirkan yaitu usia 20-35 tahun. Kulit utuh pada dewasa muda yang sehat merupakan suatu barier yang baik terhadap trauma mekanis dan juga infeksi, begitupun yang berlaku pada efisiensi sistem imun, sistem kardiovaskuler dan sistem respirasi yang memungkinkan penyembuhan luka lebih cepat. Sementara usia > 35 tahun fungsi-fungsi organ reproduksi mulai menurun, sehingga berisiko untuk menjalani kehamilan, karena usia 35 tahun atau lebih merupakan kriteria kehamilan risiko tinggi (KRT), setiap kehamilan dengan faktor risiko tinggi akan menghadapi ancaman morbiditas atau mortalitas ibu dan janin, baik dalam kehamilan, persalinan maupun nifas.

Seiring dengan bertambahnya usia, perubahan yang terjadi di kulit yaitu frekuensi penggunaan sel epidermis, respon inflamasi terhadap cedera, persepsi sensoris, proteksi mekanis, dan fungsi barier kulit. Kecepatan perbaikan sel berlangsung sejalan dengan pertumbuhan atau kematangan usia seseorang, namun selanjutnya proses penuaan dapat menurunkan sistem perbaikan sel sehingga dapat memperlambat penyembuhan luka sectio caesaria. Didapatkan hasil $\rho$ value $=$ 0.121 dengan nilai $\rho(\alpha<0.05)$. Maka dapat disimpulkan bahwa Ha diterima dan Ho ditolak, artinya tidak terdapat 


\section{PROFESIONAL HEALTH JOURNAL}

Volume 2, No. 1, Desember 2020 (Hal. 22-37)

https://www.ojsstikesbanyuwangi.com/index.php/PHJ

hubungan faktor internal usia dengan proses penyembuhan luka post operasi sectio caesaria di RS Permata Bunda Malang tahun 2019.

Hal ini sejalan dengan penelitian yang di lakukan oleh oleh Nirwana Perangin (2014) di RSUD Ratu Zalecha Martapura hasil penelitian menunjukan bahwa tidak ada hubungan. Dari 153 ibu dengan usia aman, didapatkan 139 ibu $(90,8 \%)$ yang lukanya sembuh dan dari 44 ibu dengan usia tidak aman didapatkan 40 ibu $(90,9 \%)$ yang lukanya tidak sembuh. Hasil analisa statistik dengan menggunakan uji Fisher's Exact didapatkan nilai $\rho 0,628$. Dengan nilai $\rho>$ $\alpha(0,05)$, maka dapat disimpulkan bahwa Ha diterima dan Ho ditolak, artinya tidak ada hubungan usia dengan penyembuhan luka postsectio cesaria di RSUD Ratu Zalecha Martapura tahun 2013.

Sementara usia > 35 tahun fungsifungsiorgan reproduksi mulai menurun, sehingga berisiko untuk menjalani kehamilan,karena usia 35 tahun atau lebih merupakan kriteria kehamilan risiko tinggi (KRT), setiap kehamilan dengan faktor risiko tinggi akan menghadapi ancaman morbiditas atau mortalitas ibu dan janin,baik dalam kehamilan, persalinan maupun nifas. Seiring dengan bertambahnya usia,perubahan yang terjadi di kulit yaitu frekuensi penggunaan sel epidermis, respon inflamasi terhadap cedera, persepsi sensoris, proteksi mekanis, dan fungsi barier kulit. Kecepatan perbaikan sel berlangsung sejalan dengan pertumbuhan atau kematangan usia seseorang, namun selanjutnya proses penuaan dapat menurunkan sistem perbaikan sel sehingga dapat memperlambat penyembuhan luka.

Menurut hasil analisis peneliti semakin lanjut usia dapat mempengaruhi lamanya penyembuhan luka karena semakin lanjut usia respon sel dalam tubuh akan lebih lambat menyatukan jaringan kembali sehingga proses penyembuhan luka berlangsung lama, dan yang banyak didapatkan dilapangan ibu yang dewasa tua ini lebih malas menjaga kebersihan diri baik itu merawat bekas luka post sectio caesaria, bahkan tidak berani mandi karena ditakutkan lukanya basah maka dari itu bisa terjadi infeksi sehingga menghambat masa penyembuhan. Dan sebaliknya yang usia muda dapat mempercepat penyembuhan luka karena sel-sel dalam tubuh bekerja dengan cepat dalam menyatukan jaringan sehingga penyembuhan luka berlangsung cepat. Jadi usia sebenarnya berpengaruh terhadap penyembuhan luka sectio caesaria. Karena mayoritas penyembuhan luka dapat berjalan baik pada ibu dengan usia 20-35 tahun, tetapi bukan hanya faktor usia saja yang mempengaruhi proses penyembuhan luka. Berapapun usianya proses penyembuhan luka masih bisa berjalan dengan baik, karena masih ada faktorfaktor lain yang mempengaruhi proses penyembuhan luka seperti seperti, mobilisasi dini, nutrisi, dan personal hygine. 
PROFESIONAL HEALTH JOURNAL

Volume 2, No. 1, Desember 2020 (Hal. 22-37)

https://www.ojsstikesbanyuwangi.com/index.php/PHJ

\section{Identifikasi Hubungan Faktor Internal Status Gizi (Nutrisi) dengan Proses Penyembuhan Luka post Sectio Caesaria}

Berdasarkan hasil hipotesis dengan uji spearman didapatkan $(\rho=0.000 ; \alpha=$ $0,05 ; r=0,680)$. Hasil ini menunjukan bahwa ada hubungan faktor internal status gizi (nutrisi) dengan proses penyembuhan luka post sectio caesaria di RS Permata Bunda Kota Malang. Peneliti meneliti dari 35 respondenbahwa responden yang melakukan pemenuhan nutrisi dengan baik dan sembuh sebanyak 10 orang (28.6\%) dan penyembuhan luka yang tidak sembuh dan nutrisinya kurang sebanyak 6 orang (17.1\%), responden yang nutrisinya cukup dan sembuh sebanyak 17 orang (48.6\%) . Hasil penelitian ini tanda koefisien adalah positif, dengan nilai koefisien (positif) semakin status gizi (nutrisi) nya terpenuhi maka proses penyembuhan luka semakin cepat sembuh. Dengan koefisien korelasi juga dapat di tentukan kekuatan korelasi (r) yang menginterprestasikan seberapa kuat hubungan yang ditimbulkan antara 2 variabel penelitian. Hasil penelitian ini diketahui pada rentang kuat yakni 0,680 (rentang 0,60-0,799). Dengan demikian status gizi (nutrisi) menjadi faktor utama dalam proses penyembuhan luka post operasi sectio caesaria.

Nutrisi adalah faktor yang penting dalam penyembuhan luka. Setiap fase dalam penyembuhan luka memerlukan nutrisi. Kurangnya dukungan nutrisi dapat meningkatkan angka kejadian kematian dan kecacatan dalam perawatan luka. Deteksi dini status nutrisi pada pasien luka menjadi hal yang sangat penting. Deteksi dapat dimulai sejak pasien dirawat dan setelah pulang kerumah. Saat terjadi kerusakan jaringan, katekolamin dilepaskan dan terjadi peningkatan metabolik (hipermetabolik). Pada fase ini terjadi peningkatan kebutuhan kalori dan protein berlebih. Hipermetabolik pada awal kejadian luka terjadi selama 10-14 hari. Jika pada fase ini hipermetabolik teratasi, pada hari berikutnya kebutuhan metabolik tubuh kembali normal.

Penyembuhan luka secara normal memerlukan nutrisi yang tepat. Proses penyembuhan luka bergantung pada tersedianya protein, vitamin $\mathrm{A}$ dan $\mathrm{C}$, mineral renit zink dan tembaga. Kebutuhan protein dan kalori pada pasien yang luka besar cenderung lebih tinggi dari pada kebutuhan orang sehat. Asam amino diperlukan untuk sintesis protein sruktural seperti kolagen dan untuk melakukan sintesa protein yang berperan dalam proses respon imun. Malnutrisi merupakan penyebab yang sangat penting dari kelambatan penyembuhan luka (Al Fady, 2015).

Makanan yang dikonsumsi oleh ibu nifas harus bermutu, bergizi dan cukup kalori. Konsumsi menu seimbang perlu diperhatikan untuk masyarakat, sebagai contoh menu seimbang diantaranya makanan sehat yang terdiri dari nasi, lauk, sayuran dan ditambah satu telur setiap hari (Manuaba, 2015). Ibu nifas yang berpantang makan, kebutuhan nutrisi akan berkurang sehingga makanan yang dikonsumsi sebaiknya mengnadung protein, banyak cairan, sayur-sayuran dan 
PROFESIONAL HEALTH JOURNAL

Volume 2, No. 1, Desember 2020 (Hal. 22-37)

https://www.ojsstikesbanyuwangi.com/index.php/PHJ

buah-buahan. Dan ini akan mempengaruhi dalam proses penyembuhan luka post operasi Sectio Caesarea, yaitu mengakibatkan luka menjadi tidak sembuh dengan baik atau tidak normal (Manuaba, 2015).

Ibu yang nutrisinya sudah cukup akan tetapi masih mengikuti adat kebiasaan pantang makan seperti yang telah dikatakan oleh orangtua, sehingga bisa juga menyebabkan proses penyembuhan luka post operasi Sectio Caesrea menjadi kurang baik, artinya lambat penyembuhannya. Sedangkan ibu nifas yang nutrisinya sudah cukup baik maka proses penyembuhan luka post operasi Sectio Caesarea akan lebih cepat sembuh (Mas'adah, 2016). Protein juga merupakan zat makanan yang sangat penting untuk membuntuk jaringan baru, sehingga sangat baik dikonsumsi oleh ibu nifas agar luka post operasi sectio caesareacepat sembuh. Namun jika makanan berprotein ini dipantang maka proses penyembuhan luka post operasi sectio caesarea akan berjalan lambat, dan hal ini dapat memicu terjaadinya infeksi pada luka post operasi sectio caesarea (Manuaba, 2015).

Hal ini sejalan dengan penelitian yang dilakukanoleh Hasmanidar (2015), tentang faktor- faktor yang mempengaruhi lamanya penyembuhan luka post operasi sectio saesaria di RSUD Zainoel Abidin menunjukan ada hubungan antara status gizi (nutrisi) dengan proses penyembuhan luka post operasi sectio caesaria.Hasil analisa statistik menggunakan uji chisquare menunjukkan hubungan tersebut bermakna dengan $\mathrm{p}$ value $=0,025$ yang menunjukkan bahwa terdapat pengaruh usia terhadap lamanya penyembuhan luka pasca sectio caesaria. Dari 51 responden yang status gizi kurang, sebanyak 39 (76,5\%) penyembuhan luka pasca sectio caesarea terjadi lama dan dari 41 responden yang status gizi cukup, sebanyak $30(73,2 \%)$ penyembuhan luka pasca sectio caesarea terjadi cepat. Hasil analisa statistik menggunakan uji chisquare menunjukkan hubungan tersebut bermakna dengan $\mathrm{p}$ value $=0,001$ yang menunjukkan bahwa terdapat pengaruh gizi terhadap lamanya penyembuhan luka pasca sectio caesarea.

Beberapa faktor yang dapat menghambat penyembuhan luka adalah kegemukan (malnutrisi). Kegemukan terjadi karena penyimpanan lemak berlebihan di tubuh. Lemak memiliki kemampuan vaskularisasiyang kurang baik dibandingkan otot. Penyembuhan luka memerlukan pemenuhan protein, lemak, karbohidrat, vitamin, dan mineral yang adekuat dan seimbang. Jika asupan nutrisi tersebut tidak adekuat, penyembuhan luka akan terhambat. Perbaikan status nutrisi pada pasien yang melakukan tindakan pembedahan sangat penting untuk mempercepat penyembuhan luka operasi (Niainu Naesee, 2015). Kesembuhan luka operasi sangat dipegaruhi oleh suplai oksigen dan nutrisi ke dalam jaringan, Nutrisi sangat berperan dalam proses penyembuhan luka. Status nutrisi pada seseorang adalah faktor utama yang mempengaruhi proses pertumbuhan dan mempertahankan jaringan tubuh agar tetap sehat. 
PROFESIONAL HEALTH JOURNAL

Volume 2, No. 1, Desember 2020 (Hal. 22-37)

https://www.ojsstikesbanyuwangi.com/index.php/PHJ

Menurut analisis peneliti Nutrisi sangat mempengaruhi penyembuhan luka Sectio Caesarea karena nutrisi dalam masa penyembuhan luka sectio caesarea dapat membuat sel-sel jaringan dalam tubuh cepat menyatu sehingga proses penyembuhan luka Sectio Ceasarea berjalan dengan baik, hal ini yang didapatkan dilapangan bahkan masih banyak ibu-ibu yang bilang kalau banyak makan akan terjadi infeksi seperti makan ikan, minum air yang banyak, buahbuahan, telur, sehingga masih banyak ibu yang memantang makanan karena masih mempercayai mitos-mitos yang demikian maka dari itu masih banyak didapatkan ibu yang mengalami proses penyembuhan luka lambat karena infeksi.

\section{Identifikasi Hubungan Faktor Internal Mobilisasi dengan Proses Penyembuhan Luka}

Berdasarkan hasil hipotesis dengan uji spearman didapatkan $(\rho=0.000 ; \alpha=$ $0,05 ; r=0,572)$. Hasil ini menunjukan bahwa ada hubungan faktor internal status mobilisasi dengan proses penyembuhan luka post sectio caesaria di RS Permata Bunda Kota Malang. Peneliti meneliti dari 35 responden yang melakukan mobilisasi dengan baik dan sembuh sebanyak 10 orang $(28.6 \%)$ dan penyembuhan luka yang tidak sembuh 10 orang (28.6\%), responden yang cukup melakukan mobilisasi dan sembuh sebanyak 17 orang (48.6\%) dan yang mengalami penyembuhan luka tidak sembuh serta kurang mobilisassi sebanyak 4 orang (11.4\%). Hasil penelitian ini ditandai koefisien adalah positif, dengan nilai koefisien (positif) semakin melakukan mobilisasi maka proses penyembuhan luka semakin cepat sembuh. Dengan koefisien korelasi ( $\mathrm{r}$ ) yang menginterprestasikan sedang hubungan yang di timbulkan antara 2 variabel penelitian. Hasil penelitian ini di ketahui pada rentang sedang yakni 0,572 (rentang 0,40-0,599). Dengan demikian mobilisasi merupakan salah satu faktor yang mempengaruhi proses penyembuhan luka pada post sectio caesaria

Mobilisasi adalah suatu kebutuhan mendasar pada manusia yang diperlukan oleh individu untuk melakukan aktivitas sehari-hari yang berupa pergerakan sendi, sikap, gaya berjalan, latihan maupun kemampuan aktivitas (Potter \& Perry, 2015). Mobilisasi dini dilakukan secara bertahap, berikut ini merupakan penjelasan mengenai tahapan mobilisasi dini pada ibu post sectio caesaria setelah operasi, pada 6 jam pertama ibu post Sectio Caesarea harus tirah baring terlebih dahulu. Mobilisasi dini yang bisa dilakukan adalah menggerakan lengan, tangan, menggerakan ujung jari kaki dan memutar pergelangan kaki, mengangkat tumit, menenangkan otot betis serta menekuk dan menggeser kaki. Setelah 6-10 jam, ibu diharuskan untuk dapat miring ke kiri dan ke kanan mencegah thrombosis dan trombo emboli Setelah 24 jam ibu dianjurkan untuk dapat mulai belajar untuk duduk. Setelah ibu dapat duduk, dianjurkan ibu belajar untuk berjalan (Kasdu, 2015).

Mobilisasi merupakan salah satu faktor dari penyembuhan luka, karena dengan melakukan mobilisasi dapat 
PROFESIONAL HEALTH JOURNAL

Volume 2, No. 1, Desember 2020 (Hal. 22-37)

https://www.ojsstikesbanyuwangi.com/index.php/PHJ

melancarkan sirkulasi darah sehingga memenuhi nutrisi dan oksigenasi yang dibutuhkan dalam proses penyembuhan luka yang melalui peredaran darah.

Hal ini sejalan dengan penelitian yang di lakukan oleh Hasmanidar (2015), tentang faktor- faktor yang mempengaruhi lamanya penyembuhan luka post operasi sectio caesaria di RSUD Zainoel Abidin menunjukan ada hubungan antara mobilisasi dengan proses penyembuhan luka post operasi sectio caesaria.Dari 55 responden yang mobilisasi kurang, sebanyak $38(69,1 \%)$ penyembuhan luka pasca sectio caesarea terjadi lama dan dari 37 responden yang mobilisasi baik, sebanyak $25(67,6 \%)$ yang penyembuhan luka pasca sectio caesarea terjadi cepat. Hasil analisa statistik menggunakan uji chi-square menunjukkan hubungan tersebut bermakna dengan $\mathrm{p}$ value $=0,001$ yang menunjukkan bahwa terdapat pengaruh mobilisasi terhadap lamanya penyembuhan luka pasca sectio caesarea.

Menurut analisis peneliti Mobilisasi yang kurang dapat berpengaruh terhadap penyembuhan luka Sectio Caesarea, karena apabila otot-otot / badan kurang bergerak maka tubuh akan terasa kaku dan sirkulasi darah pun tidak akan lancar ke semua sistem tubuh dan bisa menghambat membentukan jaringan- jaringan baru ini akan memperlama masa penyembuhan, karena mobilisasi akan berguna bagi semua sistem tubuh kita untuk kelancaran sirkulasi darah dan paru-paru. Mobilisasi sangat banyak manfaatnya, tetapi yang didapatkan saat penelitian ibu-ibu masih takut untuk bergerak karena kalau banyak bergerak maka luka jahitan akan terbuka dan benangnya putus, sebenarnya itu tidak akan terjadi. Dan juga sebaiknya ibu yang rajin melakukan mobilisasi dan tidak takut untuk bergerak maka peredaran darah akan lancar sehingga dapat mempercepat masa penyembuhan luka post sectio caesarea.

\section{KESIMPULAN DAN SARAN}

Bedasarkan hasil penelitian yang di lakukan pada ibu post Sectio Caesarea di Rumah Sakit Permata Bunda diruang klinik kandungan dengan menggunakan pembagian kuesioner dan lembar observasi untuk mengetahui faktor- faktor internal dalam proses penyembuhan luka pada post sectio caesaria maka peneliti dapat menarik kesimpulan faktor- faktor yang dominan sebagai berikut: 1. Faktor internal status gizi (nutrisi) yang cukup sangat berpengaruh dalam proses penyembuhan luka pada post sectio caesaria, ada hubungan yang signifikan antara status gizi (nutrisi) dengan proses penyembuhan luka post operasi sectio caesaria di RS Permata Bunda Malang 2019 dengan $\rho$ value = 0,00;2. Faktor internal mobilisasi yang cukup sangat berpengaruh dalam proses penyembuhan luka pada post sectio caesaria, ada hubungan yang signifikan antara mobilisasi dengan proses penyembuhan luka post operasi sectio caesaria di RS Permata Bunda Malang 2019 dengan $\rho$ value $=0,00 ; 3$. Sedangkan untuk faktor internal usia tidak terdapat pengaruh dalam proses penyembuhan luka post operasi sectio caesaria, tidak ada hubungan yang 
signifikan antara usia dengan proses penyembuhan luka post operasi sectio caesaria di RS Permata Bunda Malang 2019 dengan $\rho$ value $=0,12$.

Saran Penulis sebagai berikut: 1 . Bagi Rumah Sakit diharapkan dapat memberikan promosi kesehatan kepada masyarakat mengenai faktor- faktor yang mempengaruhi proses penyembuhan luka post sectio caesaria melalui penyuluhan, media leaflet, dan lain- lain. Dan dalam melakukan perawatan luka post sectio caesaria agar dapat mengenali tanda-tanda inflamasi yang berlebihan seperti adanya tanda tumor (bengkak), rubor (merah), dolor (nyeri), calor (panas), functio laesa (gangguan fungsi), karena terdapatnya tanda-tanda inflamasi yang berlebihan dapat mengindikasikan adanya infeksi, dengan mengenali tanda-tanda infeksi sedini mungkin dan menerapkan manajemen perawatan luka operasi dengan baik, diharapkan dapat menurunkan angka kejadian infeks dan dapat meningkatkan mutu pelayanan keperawatan di rumah sakit, khususnya di RS Permata Bunda Malang; 2. Bagi Responden di harapkan responden dapat mengetahui faktor-faktor yang mempengaruhi proses penyembuhan luka post operasi sectio caesaria. Sehingga responden dapat berantisispasi agar luka post sectio caesaria tidak mengalami infeksi yang dapat mempengaruhi proses penyembuhan luka menjadi lambat; 3 . Bagi Peneliti Selanjutnya diharapkan dapat meneliti faktor-faktor yang mempengaruhi proses penyembuhan luka post sectio caesaria selain dari faktor usia, status gizi (nutrisi), dan mobilisasi; 4. Bagi
Mayarakat, hasil penelitian ini diharapkan masyarakat umum dapat mengetahui faktor-faktor yang mempengaruhi proses percepatan penyembuhan luka post operasi sectio caesaria yaitu nutrisi dan mobilisasi sangat berpengaruh terhadap penyembuhan luka post sectio caesaria.

\section{DAFTAR PUSTAKA}

Alvarenga MB, Francisco AA, Oliveira SMJVd, Silva FMBd, Shimoda GT,DamianiLP. Penilaian penyembuhan episiotomi: Kemerahan, Edema,Ekchymosis,Melepaskan, Perkiraann (REEDA) keandalan skala.Revistalatino-americana de enfermagem (2015); 23 (1): 162-168

Bartini, I.(2013). Buku Pintar Panduan Dan Tips hamil sehat. Yogyakarta: Nuha Medika.

Cunningham, Leveno, Bloom, Hauth, Rouse, Spong.(2015). Buku obstetri williams, Ed. 23, vol.1

Depkes RI. Angka Kematian Ibu dan Bayi. http//www.depkes.com. 2007. diakses 15 Februari 2013.

Desriva, Nia. (2011). Tingkat Kecemasan Suami Menghadapi Sectio Caesarea Pada Istri di Rumah Sakit Umum Sembiring Tahun 2011. http://reporsitori.usu.ac.id

Ekaputra, E. (2013). Evolusi manajemen luka. Jakarta: Trans Info Media.

Elisa, (2014). Hubungan Antara Status Gizi Terhadap Proses Penyembuhan Luka Post Section Caesarea. Diperoleh dari http://ppnijateng.org/Diakses pada tanggal 2 Januari 2017. 
PROFESIONAL HEALTH JOURNAL

Volume 2, No. 1, Desember 2020 (Hal. 22-37)

https://www.ojsstikesbanyuwangi.com/index.php/PHJ

Hartati S\& Maryunani A. (2015). Asuhan Keperawatan Ibu Post Partum Seksio Sesarea. Jakarta: Trans Info Media.

Jitowiyono, S \& Kristiyanasari, W.(2015). Asuhan Keperawatan Post Operasi. Yogyakarta: Nuha Medica.

Kasdu, (2013). Operasi caesarea masalah dan solusi. Edisi: I Jakarta: Puspa swara.

Kementrian Kesehatan RI.(2015). Kesehatan dalam Kerangka Sistainable Development Goals (SDG'S). Jakarta: Kementrian Kesehatan RI; 2015

Manuaba. Ilmu Kebidanan, Penyakit Kandungan, dan KB untuk Pendidikan Bidan. Jakarta: EGC, 2015.

Maryunani, (2015). Asuhan pada ibu dalam masa nifas. Jakarta. Trans.

Mas'adah. (2010). Hubungan antara Berpantangan Makanan tertentu dengan Peyembuhan Luka Perineum pada ibu Nifas. Diakses tanggal 29 September 2013
Morison J, Moya. (2015). Manajemen Luka. Jakarta: EGC

Perangin2, Nirwana, dkk. (2013). Proses Penyembuhan Luka Post Sectio Caesariadi RSUD Ratu Zalecha Martapura Tahun 2013. Jurnal Skala Kesehatan Volume 5.No 1

Potter, A. G dan Perry, P. A. (2015). Buku Ajar Fundamental Keperawatan Konsep, Proses dan Praktik. Volume 1 edisi 4. Jakarta: EGC.

Purnawati. (2014). Efektifitas Mobilisasi Dini Pada Ibu Post Partum Teradap Percepatan Proses Penyembuhan Luka Section Caesarea Fase Inflamas di RSUD Sanggau. http//www//skripsi_stikes.com.

WHO. (2015). The Global Numbers and Costs of Additionally Needed and Unnecessary Caesarean Sections Performed per Year: Overuse as a Barrier to Univeral Covereage. Health Systems Financing. WHO. 